\title{
Discriminant Analysis of Assessment Tools in Identifying Language Impairment in Korean-English Bilingual Children
}

\author{
Sungmi Hong, Dongsun Yim \\ Department of Communication Disorders, Ewha Womans University, Seoul, Korea
}

Correspondence: Dongsun Yim, PhD Department of Communication Disorders, Ewha Womans University, 52 Ewhayeodae-gil, Seodamun-gu, Seoul 03760, Korea

Tel: $+82-2-3277-6720$

Fax: $+82-2-3277-2122$

E-mail: sunyim@ewha.ac.kr

Received: April 5, 2020

Revised: April 23, 2020

Accepted: April 28, 2020

This work was supported under the framework of international cooperation program managed by the National Research Foundation of Korea (NRF2019K2A9A2A20109497).

\begin{abstract}
Objectives: This purpose of this study was to identify measurement tasks for discriminating bilingual children who have language impairment from bilingual children who have a normal language ability. Methods: Forty Korean-English bilingual children who were between 5 to 7 years old participated in the study. Tasks used in the study were standardized vocabulary tests, a parental report, learning ability tasks, and memory ability tasks. The study conducted one way and Two-way ANOVAs to examine the group difference on language ability, learning ability, and memory ability and used partial correlations to analyze the data. Results: The results of the study were first; bilingual children with language impairment were statistically lower on all language tests, learning and memory tasks compared to typically developing children. Secondly; the result of phased discrimination analysis to identify an effective measurement task, which discriminates between language impairment and language development of bilingual children, orderly illustrated K-ALDeQ, parental report and the task of memory ability. The result which analyzed the groups of bilingual children by using discriminating equation illustrated $89.5 \%$ sensitivity and $100 \%$ specificity $\left(\mathrm{y}=-104.94+(0.31 * \mathrm{~K}-\mathrm{ALDeQ})+\left(0.79^{*}\right.\right.$ Parental report)+(0.23*NWR_E)+(-0.18*NWR_ $\mathrm{K})$. Conclusion: Results indicated that it is important to assess both children's mother tongue and the second language, learning and memory ability, and reports of parents in order to measure the language ability of bilingual children. The study results can be used for identifying language impairment in bilingual children.
\end{abstract}

Keywords: Korean-English bilingual children, Discriminate analysis, Language impairment, Learning task, Memory task, Parent report
Sequential bilinguals are individuals who have established their first language to some degree before learning a second language (Kohnert, 2008). The development of language skills in two languages differs from the acquisition of one language. Sequential bilinguals may experience language interference, code-switching, and language loss (Paradis, Genesee, \& Crago, 2011). In addition, children who acquire a second language may: 1) initially use their mother tongue for a short period, 2) undergo a "silent" or "nonverbal" period during which they may rely on gestures or use few words in the second language, 3) use short and imitative sentences,
4) begin to produce his own sentences that lack grammatical rules (Paradis et al., 2011). While these linguistic characteristics are considered a natural process in learning a second language, they would be seen as problematic if monolingual children showed these symptoms, and usually these children are referred to as children with specific language impairment (SLI). Children with SLI demonstrate difficulties in language ability with normal hearing, nonverbal IQ, neurological status, oral structure, and physical and social interactions (Leonard, 1998). The prominent characteristic of children with SLI is the language deficit characterized by mor- 
phosyntactic problems such as morpheme tense agreement, boundmorpheme omission and substitution, and shorter length of utterance in comparison with age-language matched groups (Leonard, 1998; Paradis, Crago, Genesee, \& Rice, 2003; Restrepo, 1998). These linguistic characteristics are similar to errors that are shown in sequential bilinguals who are in the process of learning a second language. In other words, there is an overlap in linguistic features between bilingual children learning a second language and monolingual children with SLI. The overlap often results in misidentification of typically developing bilingual children as if they have language impairment. Thus, it is important to disentangle these two populations and accurately identify children with SLI in bilingual populations (de Jong, Cavus, \& Baker, 2010; Kohnert, 2008; Paradis, Emmerzael, \& Duyncan, 2010; Windsor, Kohnert, Lobitz, \& Pham, 2010; Yim, 2011).

With the increase in the number of the bilingual population, professionals such as speech language pathologists have faced the challenge of identifying bilingual children with LI because they demonstrate similarities in linguistic characteristics between second language (L2) learners and monolingual children with SLI (Kohnert, 2008; Paradis et al., 2010; Thordardottir, 2015). Some of the characteristics that may challenge identification of typically developing bilingual children from those with LI are as follows: 1) their ability to use two languages are unevenly distributed within and across linguistic domains, 2) they exhibit various cross-language transfers, and 3) almost all bilingual children are unique in that their language performance varies in response to relatively similar circumstances (Kohnert, 2010). Therefore, it is important to discriminate whether the characteristics are considered the normal process of second language learning or the sign of language impairment in sequential bilingual population (Kohnert, 2008). Although the need for appropriate assessment tools for identifying bilingual children with LI is well acknowledged, there is still a lack of validated language measures (Restrepo, 1998). Thus, identification of bilingual children with LI has become a key issue in clinical settings (Windsor et al., 2010). Norm-referenced standardized assessment tools are commonly used when identifying LI in a clinical setting. However, these tools are designed to measure a child's expressive and receptive language abilities compared to their monolingual peers, and the performance on these tasks are influenced by a child's experiences with the tested language. There have been studies suggesting that processing dependent tasks are less biased in identifying LI in sequential bilinguals (Kohnert, Windsor, \& Yim, 2006; Windsor, Kohnert, Loxtercamp, \& Kan, 2008; Yim, 2011). However, there are few studies which examined varieties of tasks that are found to be critical in identification of LI in bilinguals and to cover both memory and learning cognitive profiles important for language skills. Additionally, there hasn't been a study which explored the unique contribution of these experimental tasks (which highlight memory and learning) together with parental questionnaires above and beyond standardized vocabulary scores. Thus, this study examined both memory and learning that are critical for language skills. Finally, we tested two different types of parental questionnaires found to be powerful measures in identifying LI. The overall purpose of the study was to find out which combination of these tasks best predicts the LI in the bilingual population.

Standardized measurements are considered rather linguistic knowledge dependent, and the experience dependent tasks are effective when identifying LI among monolingual children who speak the test language (Campbell, Dollaghan, Needleman, \& Janosky, 1997). When using standardized tests for bilingual children with typical language development, children are often either over or under-identified (de Jong et al., 2010; Dollaghan \& Campbell, 1998; Paradis \& Crago, 2000; Windsor \& Kohnert, 2004). Using standardized assessment tasks alone does not accurately identify language impairment in sequential bilingual children (Kohnert et al., 2006). Because bilingual children tend to score in the at-risk range on standardized tests, it is difficult to distinguish between children who are in the process of learning a second language and children with LI. When bilingual children are assessed through standardized tests only, it is difficult to diagnose their language ability because the tests themselves are not culturally balanced and racial and economic prejudices may exist (Adler \& Birdsong, 1983; Kresheck \& Nicolosi, 1973; Washington \& Craig, 1992). Therefore, it is not appropriate to solely compare bilingual children's performance with the norm of the standardized test.

\section{Language Learning Tasks}

An increasing number of empirical literatures have emphasized 
the underlying cognitive processing in monolingual children with LI (Leonard et al., 2007; Miller, Kail, Leonard, \& Tomblin, 2001; Montgomery, 2000). Several studies have suggested 'linguistic processing dependent tasks' that are designed to minimize prior knowledge of language and not biased toward culturally and linguistically diverse children (Campbell et al., 1997; Ellis Weismer et al., 2000; Kohnert et al., 2006; Yim, 2011). The study of statistical learning in children with SLI found that bilingual children with LI demonstrated significantly lower performance on implicit learning compared to their typically developing peers (Evans, Saffran, \& Robe-Torres, 2009). The findings indicate that difficulty in implicit learning may underlie aspects of the language impairment in SLI (Evans et al., 2009, Yim, Kim, \& Yang, 2015). Moreover, it has been found that bilingual children with LI showed difficulty in learning new words (Oetting, Rice, \& Swank, 1995). Oetting et al. (1995) investigated Quick incidental learning (QUIL) of new words for children with and without LI. QUIL refers to children's ability to pick up meaning of a new word in context without an ostensive definition from adults (Rice, 1990). While the typically developing (TD) children demonstrated a great ability to learn and comprehend new words, the children with LI showed some word learning ability, but their comprehension was significantly lower than TD peers (Oetting et al., 1995, Yang, Yim, \& Bae, 2015). Another study has found that bilingual children with LI exhibit difficulty in generalizing invented language rules which emphasize learning piece in language skills (Roseberry \& Connell, 1991). Roseberry and Connell (1991) examined Novel Bound-Morpheme Generalization (NBMG) learning with Spanish-English bilingual children with and without LI, and the results indicated that children with LI learned the invented morpheme at a slower rate than those without LI. In addition, Pena, Quinn, and Iglesias (1992) examined a mediated learning paradigm for English-Spanish bilingual children with and without LI. They taught children labels for object and assessed Expressive One Word Picture Vocabulary Test (EOWPVT; Gardner, 1979), and they found that there was no significant difference between the two groups, which suggested that dynamic language assessment discriminated typically developing children with language differences from those with language impairment (Pena et al., 1992). Thus, the current study selected QUIL (Yang et al., 2015) and NBMG (Jo \& Yim, 2017) developed for both
Korean and English to investigate whether these learning tasks can be accurate measures combined with other experimental measures in identifying LI in bilinguals.

\section{Working Memory Tasks}

Another suggestion for assessment measures for bilingual children was the use of "processing tasks using nonlinguistic information' which does not require a prior knowledge of the tested language. Children with SLI exhibit weakness in processing tasks that require little or no language ability (Leonard, 1998). Studies of nonlinguistic tasks, such as cognitive and perceptual motor speed tasks, on children with LI have shown that children with LI were slower in response and also exhibited less accuracy compared to their TD peers (Johnston \& Ellis Wesimer, 1983; Kohnert \& Windsor, 2004; Leonard et al., 2007; Miller et al., 2001; Windsor et al., 2008). Thus, this study examined visual working memory tapped by Matrix to assess whether nonlinguistic processing dependent measure is promising in identifying LI in the bilingual population (Yim, Kim, \& Yang, 2016; Yim, Yang, \& Kim, 2015).

Aside from Matrix, Nonword Repetition (NWR) and Sentence Repetition (SR) tasks are widely used in clinical settings and investigated in research. A study by Marton and Schwrtz (2003) examined the relation between working memory and language comprehension in children with LI, and the results indicated that children with LI had more limited working memory capacity than their TD peers. Moreover, the NWR task developed by Dollaghan and Campbell (1998) indicated that children with LI demonstrated deficits in the task compared to TD children (Ellis Weismer et al., 2000). It has been found that NWR effectively distinguishes children with SLI from TD monolingual children and also from typically developing bilingual children (Ellis Weismer et al., 2000; Gathercole \& Baddeley, 1990; Kohnert et al., 2006; Archibald, 2008). Although the NWR task is apparently a simple task, it examines the ability to process new information and is less biased by experience than by knowledge-based measures (Archibald, 2008). According to Kamhi, Catts, and Davis (1984), SLI children showed significantly lower performance at monosyllabic and multisyllabic nonwords. Campbell et al. (1997) examined NWR for minority and majority groups, and found that the minority group demonstrated lower scores than the majority group on the knowledge- 
dependent test, yet they did not differ in processing dependent tasks. It suggests that NWR is a promising identifier of differentiation between language differences and language disorders (Campbell et al., 1997). Previous studies have explored NRW task in various languages such as Spanish (Calderon \& Guiterrez-Clellen, 2003), English and Swedish (Hansson, Forsberg, Lofqvist, Maki-Torkko, \& Sahlen, 2004; Sahle'n, Reuterskiold, Nettelbladt, \& Radeborg, 1999). Calderon and Guiterrez-Clellen (2003) investigated NWR task with Spanish monolingual or Spanish-English bilingual children with and without SLI. The results showed that SLI group performed significantly lower than their peers with typical language development (TD). However, very few studies have examined NWR in Asian language. Previous studies on NWR in the Cantonese language show different results showing that NWR in Cantonese was not able to distinguish children with SLI from those with TD (Stokes, Wong, Fletcher, \& Leonard, 2006). The different results were explained in terms of different structures of language; for example, Cantonese has a simpler structure compared to English. In the case of Korean, studies have suggested NWR is successful in identification of LI in monolinguals (Yim et al., 2016). One study by Lee, Kim and Yim (2013) found that NWR was able to identify LI from monolingual and bilingual TD, but this study didn't include bilingual children with LI, which is still left to a follow-up study.

Along with NWR task, the SR task is also widely used in identification of SLI (Ellis Weismer et al., 2000; Newcomer \& Hammill, 1988; Oh \& Yim, 2013; Redmond, 2005; Semel, Wiig, \& Secord, 1989; Stokes \& Fletcher, 2003; Vicari, Caselli, Gagliardi, Tonucci, \& Volterra, 2002; Volterra, Caselli, Capirci, Tonucci, \& Vicari, 2003; Wechsler, 1989). Conti-Ramsden, Botting and Faragher (2001) conducted NWR, tense marking, a third-person singular task, and SR task for differentiating children with SLI and their age-matched peers, and the results demonstrated that the best identifiers of SLI were SR and NWR in the order named. The SR task has been found to be accurate in identifying LI in Korean monolingual speaking children (Oh \& Yim, 2013; Park, Yoon, Han, \& Yim, 2014), and a similar aspect was found in Mandarin speaking children (Stokes et al., 2006). Even though NWR and SR are tasks often used to assess morphosyntax and phonology respectively (Armon-Lotem, de Jong, \& Meir, 2015), this study used both tasks for the purpose of measuring working memory, tapping children's ability to pro- cess less biased linguistic information.

So far, we have not known how NWR and SR affect Korean-English bilingual children among Korean-English bilinguals, especially in identifying LI. Also, there are few studies on assessment of L1 and L2 of bilingual children. Accordingly, this study explored both NWR and SR in Korean and English respectively to assess both L1 and L2 of bilingual children.

\section{Parental report}

A parental report has been found to be a strong and reliable measure when identifying LI in bilingual children (Paradis et al., 2010; Restrepo, 1998). Restrepo (1998) investigated parental reports on child's speech and language problems and their family history, and found that the parental reports best discriminated children with language impairment. We used two different parental questionnaires, one from Restrepo (1998) and another one by Han and Yim (2018). Paradis et al. (2010) examined whether parental reports on bilingual children's first language development would discriminate between language differences and language disorders. The Alberta Language and Development Questionnaire developed by Paradis et al. (2010), was shown to be a good discriminator in identification of language disorders, and could be a useful assessment tool for bilingual children in case direct observation of child's first language development is not possible. The Korea-ALDeQ (2018) was developed based on the English version of Paradis et al. (2010) and was previously found to be a sensitive measurein monolingual children with and without LI in the Korean population (Han \& Yim, 2018). The parental report by Restrepo (1998) and K-ALDeQ by Han and Yim, (2010) were selected in order to examine developmental history, first language development, current level of both languages, and general ability to learn or use language in a real life situations. One big difference between these two measurements is that the parental report by Restrepo (1998) does not provide standard score whereas K-ALDeQ (Han \& Yim, 2018) gives us the criteria to identify whether children fall into language disorder or not. The parental report from Restrepo (1998) was mainly used in Korea for bilingual population previously, so it was of our research interest to include K-ALDeQ to find out whether the latest parental report can also serve as a good clinical measure.

In summary, the purpose of the current study was to investigate 
a set of assessment tasks including parental reports that will discriminate bilingual children with LI from those with typical language development.

\section{Rationale for the current study}

The current study used Sensitivity and specificity to describe which task would best differentiate the two groups. Sensitivity is probability of a positive test among bilingual children with LI. Specificity is probability of a negative test among bilingual children without LI. In the case of 0.50-0.70, it shows low accuracy in discriminating language impairment. In the case of 0.70-0.90, it shows middle accuracy in discriminating language impairment. In the case of 0.90-1.00, it shows high accuracy in discriminating language impairment (Swers, 1996; Warkins, Kush, \& Schaefer, 2002). Korean-English bilingual children with LI were compared with those with typical language development in order to investigate if there are differences among study tasks. The study tasks included 'processing dependent tasks' which tap learning capacity such as QUIL and NBMG and memory ability such as visuospatial task and nonword/sentence repetition. Additionally, a parent report and the KALDeQ, were selected in order to see developmental history, first language development, current level of both languages, and general ability to learn or use language in a real life situations. Although these tasks have been found to accurately identify bilingual children with LI, the question still remains regarding which combination of these tasks is most accurately and effectively able to identify language impairment among the bilingual population. Therefore, the research addressed the following questions.

1) Are there significant differences between bilingual children with and without LI on each of the following processing-dependent measures, QUIL, NBMG, Matrix, NWR-Korean, NWR-English, SR-Korean, SR-English, Parental report and K-ALDeQ?

2) What is the optimal set of assessment tools for discriminating LI in bilingual groups?

\section{METHODS}

\section{Participants}

The participants were 40 Korean-English bilingual children aged 5;0-7;11 selected according to the five criteria as below: (1) All participants were born in Korea and regularly used Korean at home with their parents and siblings who spoke Korean. (2) They were attending domestic elementary schools, which used English immersion elementary education for at least 2 years. (3) They attended English kindergarten and were exposed to English for at least 6 hours per day. (4) They achieved scores above 85 on nonverbal intelligence in the Korean Kaufman Assessment Battery (K-ABC; Moon \& Byun, 2003). (5) Parents and teachers reported that children did not have any problems with articulation, vision, audition, or physical health and emotion. In this study, bilingual children were defined as those who used Korean at home and English at school. 21 children (Mean $=69.7$ months, $\mathrm{SD}=7.3$ ) were identified as having typical language development, and 19 children (Mean= 68.2 months, $\mathrm{SD}=7.3$ ) received a diagnosis of language impairment using the criteria provided below.

The identification of LI followed the criteria as below. Bilingual children with TD were found to be within normal range on both Korean (REVT; Kim, Hong, Kim, Jang, \& Lee, 2009) and English (PPVT-IV; Dunn \& Dunn, 2007). Bilingual children with LI were those who achieved below $-1.25 \mathrm{SD}$ in receptive vocabulary scores on the REVT and PPVT-IV. The average nonverbal intelligence score was $107.3(\mathrm{SD}=11.1)$. The two groups were not statistically different in regard to age $\left(F_{(1,38)}=.425, p>.05\right)$ or nonverbal intelligence $\left(F_{(1,38)}=.985, p>.05\right.$. The average of non-verbal score was $110.5(\mathrm{SD}=9.7)$.

\section{Materials and Procedures}

\section{Standardized assessment measures}

To measure receptive vocabulary skills in Korean and English, standardized tests, Receptive Expressive Vocabulary Test (REVT; Kim et al., 2009) and Peabody Picture Vocabulary Test-IV (PPVTIV; Dunn \& Dunn, 2007) were used. Composite scoring was applied to collect the overall receptive language score in a bid to measure a child's representative knowledge of the presented vocabulary regardless of the language, from which it is produced (Gross, Buac, \& Kaushanskaya, 2014). Consequently, if the child does not know the word in a given language $\mathrm{A}$, the child was given the option of language B. If the child knows the concept of the tested word, then the child receives score of 1 ; yet, the child does not receive 
more than 1 even if he/she knows it in both languages (Core, Hoff, Rumiche, \& Señor, 2013; Yim, Yoon et al., 2016).

\section{Parental reports}

Two Parental reports were used to obtain information from parents; the K-ALDeQ (Han \& Yim, 2018) translated in Korean and another Korean translated version of parental report from Restrepo (1998) were used. Raw scores were also used for both tasks in the analysis.

\section{Language Learning Tasks}

Quick Incidental Learning of Words (QUIL)

Fast mapping ability plays a key role in children's vocabulary development and is basic for learning. The QUIL task (Oetting et al, 1995; Yim, Kim et al., 2015) was used to assess the ability to learn novel words when children were provided with a five minute-video clip, in which novel words were embedded. In this study, a video clip was selected from QUIL tasks that contained 4 nonwords (1 noun and 3 verbs). The procedure for the QUIL tasks was as follows: The children were asked to watch the video clip. When novel words were shown on the video, the researcher stopped the video and asked the children what the novel words were referring to. If they responded correctly, the researcher praised the children and allowed them to continue watching the video. If the children responded incorrectly, the researcher made them repeat the novel word. If the children produced the novel words, the researcher praised them and allowed them to continue watching the video.

After the video was finished, the researcher checked whether the child learned the novel words. The children learned novel words in the process of modeling, imitation, and identification. The learning of novel words was checked in the process of identification. The children earned 1 point for a correct responses and 0 points for an incorrect response.

\section{Novel Bound Morpheme Generalization (NBMG)}

The NBMG task, developed by Roseberry and Connell (1991), was used to assess the ability to learn new words. In this study, two types of novel bound morphemes (noun and verb) were used. For the noun, the novel bound morpheme was a derivational suffix '-ung', which was defined as being half of an object. The NBMG task was also used to assess whether children could generalize the learned bound morphemes to other new nouns. The process for the task was divided into the learning stage, and generalization of identification for new bounded morphemes stage. In the learning stage, the researchers showed line pictures of 4 familiar objects (the sun, a cup, a chair, and a shoe). The researchers then showed 4 cards of whole object and 4 cards of a half object. With 4 cards of a half object, the children listened to the names of a half object consisting of the new bounded morpheme '-ung' (i.e., hae $\rightarrow$ haung) and then were asked to imitate them. After the imitation, the researchers asked the children to take 2 cards from among 4 cards and induced them to say the new bounded morpheme '-ung'. In the generalization of identification for new bounded morphemes stage, the researcher showed the children 6 new objects (a car, a book, soap, a balloon, a chick, and a toy). In order to elicit the new bounded morpheme, the researcher showed the cards that depicted a half of a new object to the children, and asked them to say the names of the pictures.

The new bound morpheme for the verb was introduced as follows: The researcher showed the picture with a half object and checked whether the children applied the new bound morpheme for the noun, '-ung'. Then, the researcher showed a picture, in which an adult was hiding a half object behind his or her back, and provided the new bound morpheme '-sio'. The children earned 1 point for a correct response and 0 points for an incorrect response.

\section{Working Memory Tasks}

\section{Matrix}

A task with a visual sketch pad was used to assess the ability of visuospatial working memory of bilingual children. The Matrix task was displayed on a tablet PC, with the levels of difficulty ranging from one to four. On the matrix consisting of a $3 \times 3$ screen, 9 squares appeared in serial order and disappeared every 0.5 seconds. When the stop sign appeared on the screen, the children were asked to the touch squares in the reverse order to measure working memory. A previous study showed that when children were asked to recall the sequence in forward, there was no difference between the TD and LI group (Yim, Kim et al., 2016). There were 5 practice items and a total of 18 items, containing four items of condition 1 to recall two sequences in the reverse order, five of condition 2, 3, 
4 , in which three, four and five sequences to be recalled. The children earned one point when they answered correctly (Yim, Yang et al., 2015).

\section{Non-word repetition (NWR)}

The NWR tasks were used to determine phonological short term memory capacity. In this study, non-word repetition tasks were examined for both Korean and English. Non-word repetition tasks in Korean were adapted from those of Lee, Yim and Sim (2012) that consisted of a total of 20 words (4 words in each 2, 3, 4, 5, 6 syllables). NWR tasks in English were adapted from those of Dollaghan and Campbell (1998). In this task, the children were asked to say 20 non-words that were being heard. For the scoring, the percentage of correct consonants was applied since this is a better and accurate way to measure in Korean NWR task followed by a previous study (Yim et al., 2016). Thus, vowels were disregarded and common distortions were disregarded; yet there were no distortions in this population (Shriberg, Austin, Lewis, McSweeny, \& Wilson, 1997).

\section{Sentence repetition (SR)}

The SR tasks were examined in both Korean and English re- spectively. The task consisted of 36 sentences including a single sentence of 3 words and 5 words as well as complex sentences consisting of compound sentences (Park et al., 2014). Stimuli for SR task in English were a list of sentences from the Clinical Evaluation of Language Fundamentals, 4th edition (CELF-4; Semel, Wiig, \& Secord, 2003). In this task, the children were asked to repeat sentences that were being heard. For the scoring, the number of correct syllables was divided by the total number of syllables for Korean version of SR and the percent accuracy was calculated for the English version of SR.

\section{Analysis}

The study conducted one-way ANOVA and two-way ANOVA to examine the group difference on all dependent variables. Finally, the stepwise discriminant analysis was used to identify which assessment tools best discriminate bilingual children with LI from bilingual children without LI. Discriminant analysis significance was measured by the followings: a $p$-value of $0.50-0.70$ indicates low accuracy in discriminating language impairment, 0.70-0.90 indicates middle accuracy to discriminate language impairment, and 0.90-1.00 indicates high accuracy to discriminate language impairment (Swers, 1996; Warkins et al., 2002).

Table 1. Participant description information

\begin{tabular}{|c|c|c|c|c|c|c|c|}
\hline & \multicolumn{3}{|c|}{ Bilingual children without language impairment } & \multicolumn{3}{|c|}{ Bilingual children with language impairment } & \multirow{2}{*}{$p$} \\
\hline & Mean (SD) & Max & Min & Mean (SD) & Max & Min & \\
\hline Age (mo) & $69.7(7.3)$ & 81 & 60 & $68.2(7.3)$ & 80 & 60 & .518 \\
\hline Nonverbal I0 ${ }^{\mathrm{a}}$ & $110.5(9.7)$ & 128 & 92 & $107.3(11.1)$ & 132 & 88 & .327 \\
\hline ALDe0 (Paradis et al., 2010) & $87.6(7.0)$ & 100 & 76 & $69.2(11.3)$ & 86 & 60 & .000 \\
\hline REVT & $79.0(16.2)$ & 115 & 54 & $52.2(11.1)$ & 62 & 24 & .000 \\
\hline PPVT & $108.4(29.7)$ & 183 & 67 & $69.8(17.0)$ & 106 & 28 & .000 \\
\hline QUIL & $45.2(14.7)$ & 80 & 20 & $31.6(16.4)$ & 60 & 0 & .008 \\
\hline NBMG & $85.7(12.1)$ & 100 & 60 & $61.1(33.7)$ & 100 & 0 & .003 \\
\hline NWR_K & $89.1(4.6)$ & 98.8 & 80 & $84.0(12.1)$ & 96.3 & 50 & .029 \\
\hline NWR_E & $88.2(7.0)$ & 95 & 72.5 & $77.6(11.9)$ & 100 & 55 & .017 \\
\hline SR_K & $94.5(3.9)$ & 100 & 84.6 & $83.7(13.9)$ & 97.5 & 34 & .044 \\
\hline SR_E & $4.4(4.3)$ & 16.7 & 0 & $5.9(11.1)$ & 40.7 & 0 & .059 \\
\hline MATRIX & $41.3(21.4)$ & 88.9 & 5.6 & $27.6(20.6)$ & 75 & 0 & .048 \\
\hline Parental report (Restrepo, 1998) & $96.4(4.8)$ & 100 & 87.5 & $90.3(10.2)$ & 100 & 56.3 & .020 \\
\hline
\end{tabular}

REVT = Receptive Expressive Vocabulary Test (Kim et al., 2009); PPVT = Peabody Picture Vocabulary Test-IV (Dunn \& Dunn, 2007); QUIL= Quick Incidental Learning; NBMG= Novel Bound Morpheme Generalization; NWR-K = Nonword Repetition-Korean; NWR-E= Nonword Repetition-English; SR-K=Sentence Repetition-Korean; SR-E=Sentence Repetition-English.

${ }^{a}$ Nonverbal IO was measured with Korean Kaufman Assessment Battery for Children (K-ABC; Moon \& Byun, 2003),

${ }^{*} p<.05,{ }^{* *} p<.01$. 


\section{RESULTS}

\section{Group performance on language, learning and memory tasks (Table 1)}

A One-way ANOVA was used to compare group difference in standardized language ability tasks, REVT and PPVT. In the REVT task, there was a statistically significant difference between the two groups $\left(F_{(1,38)}=36.47, p=.000\right)$. Bilingual children with LI $($ Mean $=52.2, \mathrm{SD}=11.1)$ performed significantly lower than bilingual children with NL $($ Mean $=79, \mathrm{SD}=16.2)$. In the PPVT-IV task, the difference between the two groups was statistically significant $\left(F_{(1,38)}=24.79, p=.000\right)$. The performance of bilingual children with LI $($ Mean $=69.8, \mathrm{SD}=17)$ was significantly lower than bilingual children with NL (Mean $=108.4 \%, S D=29.7)$.

For learning tasks, One-way ANOVA was used to compare group difference in language learning tasks, QUIL and NBMG. In the QUIL task, there was a statistically significant difference between the two groups $\left(F_{(1,38)}=7.71, p=.008\right)$. Bilingual children with LI $($ Mean $=31.6 \%, \mathrm{SD}=16.4)$ performed significantly lower than bilingual children with $\mathrm{NL}(\mathrm{Mean}=45.2 \%, \mathrm{SD}=14.7)$. In the NBMG task, the difference between the two groups was statistically significant $\left(F_{(1,38)}=9.90 p=.003\right)$. The performance of bilingual children with $\mathrm{LI}($ Mean $=61.1 \%, \mathrm{SD}=33.7)$ was significantly lower than bilingual children with NL (Mean $=85.7 \%, \mathrm{SD}=12.1)$.

For MATRIX task, a one way ANOVA was used, and a two-way ANOVA was used to compare group difference on the NWR and SR tasks. In the MATRIX task, there was a statistically significant difference between the two groups $\left(F_{(1,38)}=4.19, p=.048\right)$. Bilingual children with LI (Mean $=27.6 \%, \mathrm{SD}=20.6)$ performed significantly lower than bilingual children with NL (Mean $=41.3 \%, \mathrm{SD}=21.4)$.

In NWR tasks, the difference between groups was statistically significant $\left(F_{(1,38)}=8.93, p=.005\right)$. The performance of bilingual children with LI (Mean $=80.8 \%, \mathrm{SD}=12)$ was significantly lower than bilingual children with NL $($ Mean $=88.6 \%, \mathrm{SD}=5.8)$. Moreover, there were statistically significant differences between the two groups as a function of NWR subtypes $\left(F_{(1,38)}=7.01, p=.012\right)$. In NWR-K, bilingual children with LI $($ Mean $=84 \%, S D=12.1)$ performed significantly lower than bilingual children with NL (Mean $=89.1 \%, \mathrm{SD}=4.6)$. The results were similar in the NWR-E task. In the NWR-E task, there was a statistically significant dif- ference between the two groups $\left(F_{(1,38)}=4.10, p=.017\right)$. Bilingual children with LI (Mean $=77.6 \%, \mathrm{SD}=11.9)$ performed significantly lower than bilingual children with NL (Mean $=88.2 \%, \mathrm{SD}=7)$. In addition, there was significant group NWR interaction $\left(F_{(1,38)}=\right.$ $4.10, p=.05)$ indicating that the group performance on NWR-E task was differentially greater than NWR-K.

In the SR task, the difference between groups was statistically significant $\left(F_{(1,38)}=4.48, p=.041\right)$. The performance of bilingual children with LI (Mean $=44.8 \%, \mathrm{SD}=12.5)$ was significantly lower than bilingual children with NL (Mean $=49.7 \%, \mathrm{SD}=4.1)$. There were statistically significant differences between the two groups as a function of SR subtypes $\left(F_{(1,38)}=7.01, p=.000\right)$. In the SR-K task, bilingual children with LI (Mean $=83.7 \%, \mathrm{SD}=13.9)$ performed significantly lower than bilingual children with NL (Mean $=94.5 \%$, $\mathrm{SD}=3.9)$. Similarly, bilingual children with LI (Mean $=5.9 \%, \mathrm{SD}=$ 11.1) performed more poorly than bilingual children with NL (Mean= $4.4 \%, \mathrm{SD}=4.3)$ in SR-E task. There was a significant group SR interaction $\left(F_{(1,38)}=10.62, p=.002\right)$ indicating that the group performance on the SR-K task was significantly greater than the SR-E task.

\section{Discrimination analysis}

Stepwise discriminant analysis was used to identify the most accurate combinations of tasks to differentiate bilingual children with LI from those with NL. Among all variables, the results indicated that K-ALDeQ, Parental report, NWR-E and NWR-K were the significant discriminant variables in the order named. The value of Wilks' Lambda on each task was statistically significant (Table 2). Additionally, the value of canonical correlation coefficient presented an intimate relation degree between groups, and

Table 2. Stepwise discriminant analysis results

\begin{tabular}{|c|c|c|c|}
\hline Step & Task & Wilks lambda & $F$ \\
\hline 1 & ALDeO & .45 & $47.27^{* * *}$ \\
\hline 2 & Parental Report & .35 & $34.31^{* * *}$ \\
\hline 3 & NWR-E & .31 & $27.29^{* * *}$ \\
\hline 4 & NWR-K & .27 & $23.17^{* * *}$ \\
\hline Wilks lambda & Eigenvalue & $\%$ of variance & $\begin{array}{l}\text { Canonical } \\
\text { correlation }\end{array}$ \\
\hline $0.27^{* * *}$ & 3 & 100 & 0.85 \\
\hline
\end{tabular}

NWR-K= Nonword Repetition-Korean; NWR-E= Nonword Repetition-English. ${ }^{* * *} p<.001$. 
Table 3. Sensitivity and specificity through final sort discriminant

\begin{tabular}{lccc}
\hline & $\begin{array}{c}\text { Bilingual children } \\
\text { with LI }\end{array}$ & $\begin{array}{c}\text { Bilingual children } \\
\text { with LI }\end{array}$ & Total \\
\hline Normal development & $21(100 \%)$ & $0(0 \%)$ & 21 \\
Language impairment & $2(10.5 \%)$ & $17(89.5 \%)$ & 19 \\
All groups & 23 & 17 & 40 \\
\hline
\end{tabular}

Values are presented as number (percentage).

$\mathrm{LI}=$ language impairment

Table 4. Final sort discriminant function

\begin{tabular}{lcc}
\hline & Bilingual children with LI & Bilingual children with LI \\
\hline ALDe0 & 1.811 & 1.505 \\
Parental Report & 17.691 & 16.899 \\
NWR-E & 2.062 & 1.834 \\
NWR-K & -1.132 & -.957 \\
(Constant) & -999.47 & -894.53 \\
\hline \multicolumn{3}{c}{ Final sort discriminant } \\
\hline$y=-104.94+\left(0.31^{*}\right.$ ALDe0)+(0.79*Parental report)+(0.23*NWR_E)+(0.18*NWR_K)
\end{tabular}

the discriminant score was .85 , which showed a high coefficient of correlation.

Table 3 shows sensitivity and specificity of the final sort discriminant. The discriminant analysis precisely sorted 17 of 19 bilingual children with language impairment indicating $89.5 \%$ sensitivity and sorted all out of 21 bilingual children without language impairment indicating $100 \%$ specificity.

Lastly, a final sort discriminant analysis provided discriminant function to predict bilingual children with LI from those without LI. The results showed $89.5 \%$ of sensitivity and $100 \%$ of specificity $\left(y=-104.94+\left(0.31^{\star} \mathrm{K}-\mathrm{ALDeQ}\right)+\left(0.79^{*}\right.\right.$ Parental report $)+\left(0.23^{*} \mathrm{NWR}\right.$ E)+(-0.18*NWR_K, Table 4). The sensitivity and specificity for each task that discriminated bilingual children with LI from those with TD, and reflected accuracy of diagnosis, are indicated in Table 5 .

\section{DISCUSSION \& CONCLUSION}

The goal of the current study was to examine the assessment measures in an attempt to identify the most accurate combinations of these tools that can discriminate bilingual children with LI from those without LI. This study was designed to investigate the importance of using all assessment measures grouped as lexical skills which were assessed by REVT and PPVT, learning tasks
Table 5. Sensitivity and specificity on each task

\begin{tabular}{lcc}
\hline & Sensitivity (\%) & Specificity (\%) \\
\hline ALDe0 & $78.9(15 / 19)$ & $95.2(20 / 21)$ \\
QUIL & $52.6(10 / 19)$ & $71.4(15 / 21)$ \\
NBMG & $47.4(9 / 19)$ & $76.2(16 / 21)$ \\
NWR-K & $52.6(10 / 19)$ & $61.9(13 / 21)$ \\
NWR-E & $68.4(13 / 19)$ & $71.4(15 / 21)$ \\
SR-K & $68.4(13 / 19)$ & $95.2(20 / 21)$ \\
SR-E & $26.3(5 / 19)$ & $76.2(16 / 21)$ \\
MTRIX & $63.2(12 / 19)$ & $52.4(11 / 21)$ \\
Parental Report & $63.2(12 / 19)$ & $90.5(19 / 21)$ \\
\hline
\end{tabular}

ALDeQ = Alberta Language and Development Questionnaire; QUIL = Quick incidental learning of words; NBMG = Novel Bound-Morpheme Generation; NWR-K= Nonword Repetition_Korean; NWR_E= Nonword Repetition_English; SR-K=Sentence Repetition_English; MATRIX=Visuo-Spatial Sketch Pad.

(QUIL and NBMG), memory tasks (MATRIX, NWR-K and SR-K and NWR-K and SR-E), and parental reports (a parental report and K-ALDeQ). Subtests of each task were examined by a stepwise discriminant analysis to identify which set of assessment tools best discriminated bilingual children with LI from those without LI with a high level of accuracy.

The first research question was to compare bilingual children with without LI on these tasks. The overall results confirmed that bilingual children with LI performed more poorly than those without LI on all of the measurements. The study results showed that bilingual children with LI performed less accurately on processing-dependent tasks which tap learning and memory cognitive profiles. Thus, it was confirmed that bilingual children with LI have difficulties in dealing with linguistic and non-linguistic information which leads to their limited ability to use general learning strategies when acquiring new words, or rules.

Additionally, both groups were found to be significantly different on both parental reports (Han \& Yim, 2018; Restrepo, 1998). These results supported the hypothesis that information gathered from parents is critical in identifying that bilingual children with LI differed from bilingual children without LI in the family history, developmental history, first language development, current level of both languages, and general ability to learn or use language in a real life situation.

The second research question was to find the optimal set of assessment tools for discriminating LI in bilingual groups. The stepwise discriminant analysis showed that the five assessment mea- 
sures were found to be accurate discriminators between bilingual groups. A final discriminant analysis revealed that the effective tasks were K-ALDeQ, Parental Report, NWR_E and NWR-K in the order named.

As a result of the analysis of the degree of performance using final discriminant, 17 out of 19 bilingual children with language impairment were discriminated as having language impairment; a rate of $89.5 \%$ sensitivity was shown. 21 out of 21 bilingual children with normal development were discriminated as having normal development; therefore $100 \%$ specificity was shown.

Through gradual discrimination analysis, four out of nine tasks reached an $85 \%$ variance in discriminating bilingual children with language impairment. The minimal standard for the accuracy of discrimination is $80 \%$ (Plante \& Vance, 1994) and our results were $85 \%$. Thus, our final discriminant $\left(y=-104.94+\left(0.31^{*} \mathrm{ALDeQ}\right)+\right.$ $(0.79 *$ Parental report $)+\left(0.23^{\star} \mathrm{NWR}-\mathrm{E}\right)+\left(0.18^{\star} \mathrm{NWR}-\mathrm{K}\right)$ was considered adequate to be used as a clinical index of language impairment. In summary, the first noticeable findings from these analyses are that the K-ALDeQ (Han \& Yim, 2018) and parental report (Restrepo, 1998), in which the information is obtained via parents, are very powerful in discriminating bilingual with LI from without LI. It was shown that the information from the parental report was an accurate tool enough to discriminate bilingual children with LI (Han \& Yim, 2018; Restrepo, 1998; Paradis et al., 2010). In particular, children's language ability in the mother tongue (L1), and parental report are key factors in indicating language impairment. Information about the L1, which pathologists cannot directly assess, can be found through parental reports and used for language assessment of bilingual children (Paradis et al., 2010). Through the parental interview, information on language development, which cannot be obtained directly, such as bilinguals' language case history, current language skills, noun-phrase agreement skills, ability to follow directions, ability to retrieve words, comparisons of children's abilities to their peers, can be obtained (Kayser, 1995). Also, a positive family history for speech, language, and academic problems can be identified through a parental interview (Tallal, Ross, \& Curtiss, 1989). A parental report is especially important in assessing children without norm-referenced measures (Restrepo, 1998). The present study used parental reports as an assessment tool, and results showed that the parents of bilingual children with
LI reported lower performance of their children's language ability compared to parents of bilingual children with NL. Thus, as shown in previous research (Dale, 1991; Gutierrez-Clellen, Palacios, \& Thal, 1992; Hadley \& Rice, 1993), parental reports were judged to be valid in identifying bilingual children with LI, and they also provided precise information regarding current language ability of children. Moreover, previous studies reported that the sensitivity of parental reports in language development checklists ranged from $75 \%$ to $90 \%$ (Rescorla, Hadicke-Wiley \& Escarce, 1993). The results of the ALDeQ used in this study showed 78.9\% sensitivity and $95.2 \%$ specificity, indicating that parental reports are an effective tool enough to discriminate bilingual children with LI.

The second important findings are that the NWR tasks in both Korean and English were crucial measures in diagnosing bilinguals with LI, along with parental reports. NWR has been widely used both in clinical settings and research settings by virtue of its simple scoring system and a relatively short duration of an administration. However, it is important to highlight that the discriminant analyses showed that both languages of NWR should have been included, not limited to only one. Thus, from the clinicians' viewpoint, both the child's first and second languages should be tested when using NWR. Even though NWR measures a basic phonological working memory that is linked to specific language phonological system, in our opinion, it is obviously a powerful diagnostic tool when used with parental reports and when administered in both languages.

In conclusion, this study identified the set of assessment tasks which aimed to reduce the factors leading to the over and underdiagnosis of LI by assessing the parental reports, and the tasks of memory \& learning. A combination of parental report and phonological working memory in both languages was found to be a successful predictor in identifying LI for Korean-English bilinguals. Bilingual children are exposed to culturally and linguistically varied environments and the language development of bilingual children is different from that of monolingual children; therefore, in addition to standardized tools, parental reports as well as cognitive tasks, which tapped working memory in this study, should be definitely included when identifying LI in bilinguals. 


\section{REFERENCES}

Adler, S., \& Birdsong, S. (1983). Reliability and validity of standardized testing tools used with poor children. Topics in Language Disorders, 3(3), 7688.

Armon-Lotem, S., de Jong, J., \& Meir, N. (2015). Assessing Multilingual Children. Disentangling Bilingualism from Language Impairment. Bristol: Multilingual Matters.

Archibald, L. M. D. (2008). The promise of non-word repetition as a clinical tool. Canadian Journal of Speech Language Pathology and Audiology, 32(1), 21-28.

Calderon, J., \& Gutierrez-Clellen, V. (2003). Nonword repetition in emerging bilingual children with language impairment. Proceedings of the 4 th International Symposium on Bilingualism, Tempe, AZ.

Campbell, T., Dollaghan, C., Needleman, H., \& Janosky, J. (1997). Reducing bias in language assessment: processing dependent measures. Journal of Speech, Language, and Hearing Research, 40(3), 519-525.

Conti-Ramsden, G., Botting, N., \& Faragher, B. (2001). Psycholinguistic markers for specific language impairment (SLI). Journal of Child Psychology and Psychiatry, 42(6), 741-748.

Core, C., Hoff, E., Rumiche, R., \& Señor, M. (2013). Total and conceptual vocabulary in Spanish-English bilinguals from 22 to 30 months: implications for assessment. Journal of Speech, Language, and Hearing Research, 56(5), 1637-1649.

Dale, P. (1991). The validity of a parent report measure of vocabulary and syntax at 24 months. Journal of Speech and Hearing Research, 34(3), 565571.

de Jong, J., Cavus, N., \& Baker, A. (2010). Language impairment in Turkish Dutch bilingual children. In S. Topbas \& M. Yavas (eds), Communication Disorders in Turkish (pp. 288-300). Bristol, UK: Multilingual Matters.

Dollaghan, C., \& Campbell, T. (1998). Non-word repetition and child language impairment. Journal of Speech, Language, and Hearing Research, 41(5), 1136-1146.

Dunn, M., \& Dunn, L. M. (2007). Peabody Picture Vocabulary Test-4. Circle Pines, MN: AGS.

Ellis Weismer, S., Tomblin, J. B., Zhang, X., Buchwalter, P., Chynoweth, J. G., \& Jones, M. (2000). Nonword repetition performance in school age children with and without language impairment. Journal of Speech, Language, and Hearing Research, 43(4), 865-878.

Evans, J. L., Saffran, J. R., \& Robe-Torres, K. (2009). Statistical learning in children with specific language impairment. Journal of Speech, Language, and Hearing Research, 52(2), 321-335.

Gathercole, S., \& Baddeley, A. (1990). Phonological memory deficits in language disordered children: is there a causal connection? Journal of Memory and Language, 29(3), 336-360.

Gardner, M. E. (1979). The Expressive One Word Picture Vocabulary Test. Novato, CA; Academic Therapy Publications.

Gross, M., Buac, M., \& Kaushanskaya, M. (2014). Conceptual scoring of receptive and expressive vocabulary measures in simultaneous and sequential bilingual children. Journal of Speech, Language, and Hearing Research, 23(4), 574-586.

Gutierrez-Clellen, V. F., Palacios, M., \& Thal, D. (1992). The validity of parental report with Spanish-speaking toddlers. Poster presented at the annual convention of the American Speech Language Hearing Association in San Antonio, Texas.

Hadley, P. A., \& Rice, M. L. (1993). Parental judgements of preschoolers' speech and language development: a resource for assessment and IEP planning. Seminars in Speech and Language, 14(4), 278-288.

Han, J., \& Yim, D. (2018). Korean brief parent report measures of language development in children with vocabulary delay. Journal of Speech-Language \& Hearing Disorders, 27(2), 69-84.

Hansson, K., Forsberg, J., Lofqvist, A., Maki-Torkko, E., \& Sahlen, B. (2004). Working memory and novel word learning in children with hearing impairment and children with specific language impairment. International Journal of Language and Communication Disorders, 39(3), 401-422.

Jo, Y. J., \& Yim, D. (2017). Performance on the Novel Bound-Morpheme Generalization (NBMG) Task in Korean-English bilingual children. Сотmunication Sciences and Disorders, 22(1), 1-24.

Johnston, J., \& Ellis Weismer, S. (1983). Mental rotation abilities in languagedisordered children. Journal of Speech and Hearing Research, 26(3), 397403.

Kamhi, A., Catts, H., \& Davis, M. (1984). Management of sentence production demands. Journal of Speech and Hearing Research, 27(3), 329-337.

Kayser, H. (1995). Assessment of speech and language impairments in children. In H. Kayser (Ed.), Bilingual speech and language pathology: an Hispanic focus (pp. 243-264). San Diego, CA; Singular.

Kim, Y. T., Hong, K. H., Kim, K. H., Jang, H. S., \& Lee, J. Y. (2009). Receptive and expressive vocabulary test. Seoul: Seoul Community Rehabilitation Center.

Kohnert, K. (2008). Language disorders in bilingual children and adults. San 
Diego, CA: Plural.

Kohnert, K. (2010). Bilingual children with primary language impairment: issues, evidence and implications for clinical actions. Journal of Communication Disorders, 43(6), 456-473.

Kohnert, K., \& Windsor, J. (2004). The search for common ground: part II. Nonlinguistic performance by linguistically diverse learners. Journal of Speech, Language, and Hearing Research, 47(4), 891-903.

Kohnert, K., Windsor, J., \& Yim, D. (2006). Do language based processing tasks separate children with language impairment from typical bilinguals? Language Disabilities Research and Practice, 21(1), 19-21.

Kresheck, I., \& Nicolosi, S. (1973). A comparison of Black and White children's score on the PPVT. Language, Speech, and Hearing Services in Schools, $4(1), 37-40$.

Lee, H. J., Kim, Y. T., \& Yim, D. (2013). Non-word repetition performance in Korean-English bilingual children. International Journal of Speech-Language Pathology, 15(4), 375-382.

Lee, Y., Yim, D., \& Sim, H. (2012). Phonological processing skills and its relevance to receptive vocabulary development in children with early cochlear implantation. International Journal of Pediatric Otorhinolaryngology, 76(12), 1755-1760.

Leonard, L. (1998). Children with Specific Language Impairment. Cambridge, MA: MIT Press.

Leonard, L., Ellis Weismer, S., Miller, C., Francis, D., Tomblin, J. B., \& Kail, R. (2007). Speed of processing, working memory, and language impairment in children. Journal of Speech, Language, and Hearing Research, 50(2), 408428.

Marton, K., \& Schwartz, R. G. (2003). Working memory capacity and language processes in children with specific language impairment. Journal of Speech, Language \& Hearing Research, 46(5), 1138-1153.

Miller, C., Kail, R., Leonard, L., \& Tomblin, J. B. (2001). Speed of processing in children with specific language impairment. Journal of Speech, Language, and Hearing Research, 44(2), 416-433.

Montgomery, J. W. (2000). Verbal working memory and sentence comprehension in children with specific language impairment. Journal of Speech, Language, and Hearing Research, 43(2), 293-308.

Moon, S. B., \& Byun, C. J. (2003). Korean Kaufman Assessment Battery for Children (K-ABC). Seoul: Hakjisa.

Newcomer, P. L., \& Hammill, D. D. (1988). The Test of Language Development. Austin, TX: Empiric Press.

Oetting, J. B., Rice, M. L., \& Swank, L. K. (1995). Quick incidental learning
(QUIL) of words by school-age children with and without SLI. Journal of Speech, Language, and Hearing Research, 38(2), 434-445.

Oh, D. Y., \& Yim, D. (2013). Non-word repetition and sentence repetition performance in 2-3 years old late talkers and normal children. Korean Journal of Communication \& Disorders, 18(3), 277-287.

Paradis, J., \& Crago, M. (2000). Tense and temporality: a comparison between children learning a second language and children with SLP. Journal of Speech, Language, and Hearing Research, 43(4), 834-847.

Paradis, J., Crago, M., Genesee, F., \& Rice, M. (2003). Bilingual children with specific language impairment: how do they compare with their monolingual peers? Journal of Speech, Language and Hearing Research, 46, 1-15.

Paradis, J., Emmerzael, K., \& Duyncan, T. S. (2010). Assessment of English language learners: using parent report on first language development. Journal of Communication Disorders, 43(6), 474-497.

Paradis, J., Genesee, F., \& Crago, M. B. (2011). Dual language development \& disorders: a handbook on bilingualism \& second language learning (2nd Ed.). Baltimore, MD: Paul H. Brookes Publishing Co, Inc.

Park, W., Yoon, S., Han, B., \& Yim, D. (2014). A comparison of scoring methods on the sentence repetition test in Korean children with delayed language development. Journal of Speech-Language \& Hearing Disorders, 23(1), 17-29.

Pena, E. D., Quinn, R., \& Iglesias, A. (1992). The application of dynamic methods to language assessment: a nonbiased procedure. The Journal of Special Education, 26(3), 269-279.

Plante, E., \& Vance, R. (1994). Selection of preschool language tests: a databased approach. Language, Speech, and Hearing Services in Schools, 25(1), $15-24$.

Redmond, S. M. (2005). Differentiating SLI from ADHD using children's sentence recall and production of past tense morphology. Clinical Linguistics and Phonetics, 19(2), 109-127.

Rescorla, L., Hadicke-Wiley, M., \& Escarce, E. (1993). Epidemiological investigation of expressive language delay at age two. First Language, 13(37), $5-22$.

Restrepo, A. (1998). Identifiers of predominately Spanish speaking children with language impairment. Journal of Speech, Language and Hearing Research, 41(6), 1398-1411.

Rice, M. L. (1990). Preschooler's QUIL: Quick incidental learning of words. In G. Conti-Ramsden \& C. E. Snow (Eds.), Children's language, (pp. 171-196). Hillsdale, NJ: Erlbaum.

Roseberry, C. A., \& Connell, P. J. (1991). The use of an invented language 
rule in the differentiation of normal and language-impaired Spanish-speaking children. Journal of Speech, Language and Hearing Research, 34(3), 596603.

Sahle’n, B., Reuterskiold, W. C., Nettelbladt, U., \& Radeborg, K. (1999). Nonword repetition in children with language impairment pitfalls and possibilities. International Journal of Language and Communication Disorders. 34(3), 337-351.

Semel, E. M., Wiig, E., \& Secord, W. (1989). CELF-R screening test. San Antonio, TX: Psychological Corporation.

Semel, E., Wiig, E. H., \& Secord, W. A. (2003). Clinical evaluation of language fundamentals, fourth edition (CELF-4). Toronto, Canada: The Psychological Corporation/A Harcourt Assessment Company.

Shriberg, L. D., Austin, D., Lewis, B. A., McSweeny, J. L., \& Wilson, D. L. (1997). The percentage of consonants correct (PCC) metric extensions and reliability data. Journal of Speech, Language, and Hearing Research, 40(4), 708722.

Stokes, S. F., \& Fletcher, P. (2003). Aspectual forms in Cantonese children with specific language impairment. Linguistics, 41(2), 381-405.

Stokes, S. F., Wong, A. M., Fletcher, P., \& Leonard, L. B. (2006). Nonword repetition and sentence repetition as clinical markers of specific language impairment: the case of Cantonese. Journal of Speech, Language, and Hearing Research, 49(2), 219-236.

Swers, J. A. (1996). Signal detection theory and RIC analysis in psychology and diagnosis: collected papers. Mahwah. NJ: Erlbaum.

Tallal, P., Ross, R., \& Curtiss, S. (1989). Familial aggregation in specific language impairment. Journal of Speech and Hearing Disorders, 54(2), 167 173.

Thordardottir, E. (2015). Proposed diagnostic procedures for use in bilingual and cross-linguistic contexts. In S. Armon-Lotem, J. de Jong, \& N. Meir (Eds.), Methods for assessing multilingual children: disentangling bilingualism from Language Impairment (pp. 1-22). Bristol, UK: Multilingual Matters.

Vicari, S., Caselli, M. C., Gagliardi, C., Tonucci, F., \& Volterra, V. (2002). Language acquisition in special populations: a comparison between Down and Williams syndromes. Neuropsychologia, 40(13), 2461-2470.

Volterra, V., Caselli, M. C., Capirci, O., Tonucci, F., \& Vicari, S. (2003). Early linguistic abilities of Italian children with Williams syndrome. Developmental Neuropsychology, 23(1-2), 33-58.

Warkins, M., Kush, J., \& Schaefer, B. (2002). Diagnostic utility of the learning disability index. Journal of Learning Disabilities, 35(2), 98-104.

Washington, J. A., \& Craig, H. K. (1992) Performances of low-income, African American preschool and kindergarten children on the Peabody Picture Vocabulary Test-Revised. Language, Speech, and Hearing Services in schools, 23(4), 329-333.

Wechsler, D. (1989). Wechsler Preschool and Primary Scale of IntelligenceRevised. San Antonio, TX: Psychological Corporation.

Windsor, J., \& Kohnert, K. (2004). The search for common ground: part I. Lexical performance by linguistically diverse learners. Journal of Speech, Language, and Hearing Research, 47(4), 877-890.

Windsor, J., Kohnert, K., Loxtercamp, A., \& Kan, P. F. (2008). Performance on nonlinguistic visual tasks by children with language impairment. $A p$ plied Psycholinguistics, 29(2), 237-268.

Windsor, J., Kohnert, K., Lobitz, K. F., \& Pham, G. T. (2010). Cross-language nonword repetition by bilingual and monolingual children. American Journal of Speech-Language Pathology, 19(4), 298-310.

Yang, Y., Yim, D., \& Bae, K. (2015). Predictors of word learning in children with specific language impairment. Communication Sciences \& Disorders, 20(1), 1-12.

Yim, D. (2011). Usage of statistical learning for clinical marker for bilingual children. Korean Journal of Communication Disorders, 16(1), 13-22.

Yim, D., Kim, S., \& Yang, Y. (2015). Factor analysis of working memory tasks based on information processing characteristics: predictive factors of receptive vocabulary and quick incidental learning in children with typically developing and receptive vocabulary delay. Communication Sciences \& Disorders, 20(2), 304-318.

Yim, D., Jo, Y., Han, J., \& Seong, J. (2016). Executive functioning skills in Korean-English bilingual children with and without language delay. Communication Sciences \& Disorders, 21(3), 472-487.

Yim, D., Kim, Y. T., \& Yang, Y. (2016). Exploring the utility of verbal and visuo-spatial working memory for identifying children with language impairment. Communication Sciences \& Disorders, 21(2), 193-205.

Yim, D., Yang, Y., \& Kim, S. (2015). Domain-specific working memory performance in children with and without specific language impairment. Communication Sciences \& Disorders, 20(1), 13-23.

Yim, D., Yoon, S., \& Lee, J. (2016). Receptive vocabulary assessment in Korean-English bilingual children: cross-linguistic investigations. Communication Sciences \& Disorders, 21(1), 131-138. 


\section{국문초록}

\section{한국어-영어 이중언어아동의 언어발달지체 판별연구}

\section{홍성미 · 임동선}

이화여자대학교 언어병리학과

배경 및 목적: 본 연구는 이중언어 아동의 언어발달지체를 판별하기 위한 평가 과제를 제안하고자 하였다. 방법: 이 연구에 참여한 대 상자는 5-7세 사이의 40 명의 한국어-영어 이중언어아동(정상언어발달 이중언어아동 21 명, 언어발달지체 이중언어아동 19 명)이었다. 연 구과제는 표준화된 언어검사, 부모 보고서, 학습-기억능력의 과제이다. 학습능력 과제(빠른우연학습 과제, 새로운 의존형태소학습 과 제), 기억능력 과제(작업기억 과제, 단기기억 과제)의 차이가 통계적으로 유의미한지 확인하고자 일원 혹은 이원 분산분석을 실시하였 고, 언어발달지체 이중언어아동을 판별하기 위하여 어떤 과제가 효과적인지 확인하고자 단계별 판별분석을 실시하였다. 결과: 첫째, 언 어발달지체 이중언어아동은 언어 능력과 학습 및 기억 능력 등의 측면에서 정상언어발달 이중언어아동에게서 통계적으로 낮은 수행 을 보였다. 둘째, 단계적 판별분석의 결과, 언어장애를 판별하는 민감도가 $89.5 \%$, 정상언어발달을 판별하는 특이성이 $100 \%$ 를 나타냈 다. 논의 및 결론: 이 연구는 부모보고와 함께 학습 및 기억과제를 평가하여 이중언어아동의 언어발달지체를 과잉 진단하는 위험을 줄 이고자 하였다. 이중 언어 아동의 언어 평가에는 표준화된 도구뿐만 아니라 부모 보고와 함께 다양한 학습 및 기억 과제를 평가하는 것 이 포함되어야한다.

핵심어: 한국어-영어 이중언어아동, 판별 분석, 언어발달지체, 부모보고서, 학습능력과제, 기억능력과제

본 연구는 2019년 한국연구재단 국제협력사업의 지원을 받아 수행되었음(NRF-2019K2A9A2A20109497).

\section{참고문헌}

김영태, 홍경훈, 김경희, 장혜성, 이주연(2009). 수용·표현어휘력검사(REVT). 서울: 서울장애인종합복지관.

문수백, 변창진(2003). K-ABC 교육·심리측정도구(Korean-Kaufman assessment battery for children, K-ABC). 서울: 학지사.

박원정, 윤사라, 한보연, 임동선(2014). 한국어 문장따라말하기 검사의 점수체계 비교 연구. 언어치료연구, 23(1), 17-29.

양윤희, 임동선, 배경란(2015). 학령기 단순언어장애 아동의 어휘학습 예측요인: 의미점화 및 간섭 효과. Communication Sciences \& Disorders,

20(1), 1-12.

오다연, 임동선(2013). 2-3세 말 늦은 아동과 정상 아동의 비단어따라말하기와 문장 따라말하기 수행 능력. 언어청각장애연구, 18(3), 277-287.

임동선(2011). 이중언어 사용 아동을 위한 비언어정보 통계적 학습의 진단 도구로써의 사용. 언어청각장애연구, 16(1), 13-22.

임동선, 김신영, 양윤희(2015). 정보처리 특성에 따른 작업기억 과제의 탐색적 요인분석: 일반아동 및 수용어휘지체 아동의 수용어휘력 및 빠른우연

학습 예측요인. Communication Sciences \& Disorders, 20(2), 304-318.

임동선, 김영태, 양윤희(2016). 언어장애아동 판별을 위한 구어 및 시공간적 작업기억의 효용성 탐색. Communication Sciences \& Disorders, 21(2), 193-205.

임동선, 양윤희, 김신영(2015). 단순언어장애 아동과 일반 아동의 작업기억 제시방식 및 과제유형에 따른 수행능력 비교. Communication Sciences \& Disorders, 20(1), 13-23.

임동선, 윤사라, 이지연(2016). 교차언어 연구를 통한 한국어-영어 이중언어아동의 수용어휘력 평가. Communication Sciences \& Disorders, 21(1), 131-138.

임동선, 조연주, 한지윤, 성지민(2016). 한국어-영어 이중언어사용 아동의 어휘발달지연 유무에 따른 집행기능 비교. Communication Sciences \&

Disorders, 21(3), 472-487.

조연주, 임동선(2017). 한국어-영어 이중언어 아동의 새로운 의존형태소 과제(NBMG) 수행 능력. Communication Sciences \& Disorders, 22(1), 1-24. 
한지윤, 임동선(2018). 부모 보고형 아동 언어 능력 평가도구(KBPR)의 표준화를 위한 예비연구. 언어치료연구, 27(2), 69-84.

\section{ORCID}

홍성미(제1저자, 대학원생 https://orcid.org/0000-0002-9616-1970); 임동선(교신저자, 교수 https://orcid.org/0000-0001-8254-9504) 